\title{
New Genus and Species of Diatom Endemic in Lake Rani of Haryana, India
}

\author{
Vandana Vinayak*, M. K. Goyal, Vichar Mishra
}

Forensic Science Laboratory Madhuban, Karnal, India.

Email: *kapilvinayak@gmail.com

Received June $12^{\text {th }}, 2012$; revised July $23^{\text {rd }}, 2012$; accepted August $8^{\text {th }}, 2012$

\begin{abstract}
Diatoms are unicellular plant algae which are found in almost all the waterbodies. Different diatoms respond differently to different environmental changes, there existence depending on the environmental factor of a particular place. A new diatom type was discovered in the lake Rani of Jind District of Haryana for the first time. Jind is an important district lying in the north of Haryana state located $75^{\circ} 53^{\prime}$ and $76^{\circ} 47^{\prime}$ East longitudes and between $29^{\circ} 03^{\prime}$ and $29^{\circ} 51^{\prime}$ North latitudes. It has a beautiful lake named as Rani Talab (Lake) which is famous for tourist visit and is located in the centre of the city. The $\mathrm{pH}$ of this water body ranges between 6.5 to 8.3 , conductivity between 0.21 to $0.294 \mathrm{~m} \cdot \mathrm{mho} \cdot \mathrm{cm}^{-1}$ with temperature ranging between $19.5^{\circ} \mathrm{C}$ to $35^{\circ} \mathrm{C}$ for two consecutive years 2008-2009 and 2009-2010. The newly discovered diatom is the only diatom which inhabits one particular Lake Rani of Haryana, it is not found elsewhere in India and any other database of diatoms generated so far in any other part of the world. The new genus was discovered by Vinayak V. et al. in the process of creation of diatom database from Haryana State of India for the first time. The new genus was named as Eunocymbellarania vandana for its genus name derived from Eunotia and Cymbella and its close affinity to these two diatoms and its origin place "Lake Rani", but the species name "vandana" is from Diatomist Vandana.
\end{abstract}

Keywords: Diatom; Lake Rani; New Genera

\section{Introduction}

\subsection{Origin}

Lake Rani in Jind was made by king of Jind because he didn't get the permission to visit Golden Temple in Amritsar, Punjab (India). That's why he created the same in Jind. In between the pond there is a temple of Lord Shiva (Figure 1).

\subsection{Location and Climate}

The district lies in the North of Haryana between 29.03' and 29.51' North latitude \& 75.53' and 76.47' East longitude. The area of the district is 3606 square kilometres. The climate of this district is on the whole dry, hot in summer and cold in winter. The average rainfall over the district as a whole is $55 \mathrm{~cm}$. Lake Rani water quality is deteriorating day by day as water is not replaced with fresh water and is often infiltrated with rain and nearby industrial waste water. Water at the boundaries of Lake is green coloured due to manifestation of algal growth.

\footnotetext{
"Corresponding author.
}

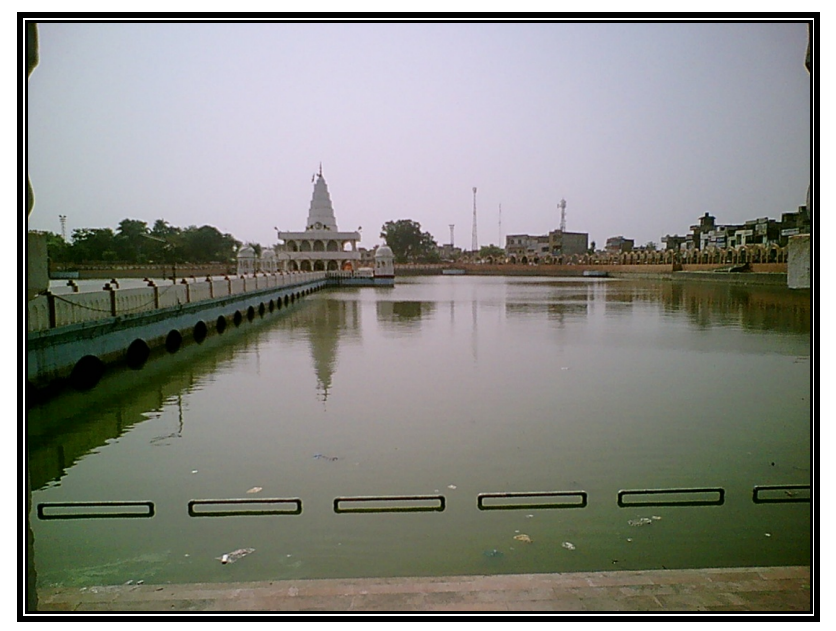

Figure 1. Lake Rani of Jind Haryana, India (LRH).

\subsection{Diatoms}

Diatoms are unicellular, autotrophic microscopic algae found in almost all aquatic habitats [1], with each habitat developing its characteristic flora existing under different chemical and physical environments [2]. Diatoms are 
delicate unicellular organisms that have a yellow-brown chloroplast that enables them to photosynthesize. Their cell walls are made of silica almost like a glass house. The construction of the cell wall, called the frustule, consists of two valves that fit into each other like a little pill box. Their size varies from 1 to $2000 \mu \mathrm{m}$, however, most species range from 10 to $100 \mu \mathrm{m}$. Diatoms can be broadly divided into two basic groups based on their symmetry, viz. "centric diatoms" exhibit radial symmetry (i.e. symmetry about a point) and "pennate diatoms" show bilateral symmetry (i.e. symmetry about an axes).

The main feature of diatoms is their siliceous cell wall (frustule). Many authors have identified abnormal morphology or disturbed ornamentation for some diatom cells, potentially as a result of exposure to xenobiotics [3-13]. Numerous toxic agents have been reported as potential inducers of diatom cell wall (frustule) abnormalities. In situ studies identified abnormal frustules in samples contaminated by heavy metals $[3,8,9,14]$ Jansen and Altenburger reported abnormal forms of diatoms exposed to high concentrations (up to $312 \mu \mathrm{g} / \mathrm{L}$ ) of isoproturon, a herbicide widely used in agriculture. Abnormal frustule morphology was also observed in diatoms exposed to microtubule inhibitors such as colchicine [15-17]. Oxidative stress due to radiation or toxic exposure may also be implicated in the induction of frustule abnormalities [18,19]. Environmental factors, such as nutrient deficiencies and $\mathrm{pH}$, may also play a role in the development of abnormal frustules [9]. In particular, severe silica deficiencies show evidence of inducing these abnormalities $[4,8]$. Among other mentioned causes for induction of abnormal frustules are the mechanical effects of high cell density in crowded communities [20]. According to Stoermer [21], abnormal frustules may constitute clones of a single cell which suffered a genetic mutation which resulted in cell wall distortion.

Another scientific study shows that silica deficiency would implicate the cytoskeleton, which is known to manage the migration of silica deposition vesicles (SDV) for cell wall synthesis [1,17,22-24]. Thus, [25] Debenest et al. suggested that disturbance of the SDV transporters would lead to poor silica supply and thereby induction of frustule abnormalities.

In the present study two genera show close affinity in a newly discovered form of diatom which might have resulted due to factors described above. However, the common features of Cymbella affinis and Eunotia bilunaris are described as under:

The genus Cymbella was founded by Agardh [26] for diatoms with "frustula elliptica libera vel muco amorpha involuta, binatim conjuncta". Agardh included in his genus cymbelloid free-living or stipitate diatoms [27].

Eunotia taxa are considered important ecological indi- cators $[28,29]$. This is essentially a freshwater diatom genus frequently associated with acidic waters $[28,30-$ $35]$ and oligotrophic or dystrophic situations [22,3638].

Diatom analysis can be of further use in forensic science through identifying the provenance of individuals, clothing or materials from sites of investigation [39-44]. Since diatom plays an important role in giving a possibility of post mortem and ante mortem deaths due to drowning in a liquid media since during drowning they along with the water enter the pulmonary venous circulation and reach the distant organs which are then acid digested, centrifuged and studied microscopically under phase contrast microscope. The detection of new diatom genus which has so far not being identified elsewhere in the studies very clearly specifies the location of death serving as a great site specific forensic marker. Besides this diatoms are known to have edible oils containing omega-3-fatty acids, in particular eicosapentaenoic acid (EPA).

\section{Materials and Methods}

Between year 2008-2009 water samples were collected from Rani lake every month with the help of plankton mesh net (size $0.5 \mathrm{~mm}$ ) between 9 to 12 noon. All the samples were preserved in $4 \%$ formaldehyde solution at the spot. Diatom frustules were cleaned following nitric acid digestion method and slides prepared. Permanent slides were prepared following the method by Patrick and Reimer [36] and photomicrographs were taken using Phase contrast Microscope. Acquired images of diatoms morphology were studied, and the main diatom floras used for identification were those of Californian Diatom Database, [1,37,45-57].

Geographical position, date of collection, sample number etc. were recorded. Several environmental variables were studied, Conductivity, $\mathrm{pH}$ and water temperature were measured using $\mathrm{pH}$ and conductivity meter.

Counting of diatoms was done by Sedgwick Rafter Chamber method given by Bernard J. Mc Alice [58].

Following formula was applied for total count of diatoms/liter:

$$
\begin{gathered}
\text { Diatoms/ml }(\mathrm{n})=\frac{\text { Diatom counted } \times 1000}{\text { Gridcells }} \\
\text { Diatoms } / \text { Liter }(\mathrm{N})=\frac{\mathrm{n} \times \mathrm{v} \times 1000}{\mathrm{~V}}
\end{gathered}
$$

where $\mathrm{n}=$ average number of diatom cells in $1 \mathrm{ml}$ of water sample

$$
\begin{gathered}
\mathrm{v}=\text { volume of water sample concentrate }(\mathrm{ml}) \\
\mathrm{V}=\text { Volume of total water (liter) }
\end{gathered}
$$




\section{Results and Discussions}

\section{Morphology}

On looking the newly identified diatom under phase contrast microscope it clearly is different from other genera of diatoms, Valve size $25 \mu \mathrm{m}$ long, dorsal side highly convex and ventral side slightly concave and notch at the ventral a little away from middle region, ends constricted, rostrate to subcapitate. Raphe slightly thick, arcutate with terminal fissures slightly bent. Striae $10-14 \mu \mathrm{m}$, radial, distinctly punctuate.The newly identified genera was first spotted in April 2009 when temperature was $32^{\circ} \mathrm{C}$, conductivity $0.21 \mathrm{~m} \cdot \mathrm{mhi} \cdot \mathrm{cm}^{-1}$ and $\mathrm{pH} 7.85$. It was named as Eunocymbellarania vandana due to its close approximity to Cymbella affinis and Eunotia bilunaris based on the relationship of raphe sternum and rib and the elongate external areola openings and its origin "Rani Lake" (Figures 2(a)-(c)), and species was named by Diatomist Vandana.

Further data (molecules or morphology) may contribute to our understanding of these relationships. Nevertheless, evidence may be based on prepared specimens in established collections. Of course, it may well be advantageous, even appropriate, to find new specimens, still living, isolate them, extract DNA sequences, analyse them, compare the results to what is already known.

Jind city in Haryana is an industrial city with lot of industry waste being flowing in Lake Rani making the water foamy and polluted at places.

Presence of this new genera and species in lake Rani is very important as it can serve as a environmental indicator of particular waste being dumped into this water body which may have resulted into evolution of this diatom. The most unique feature of Eunocymbellarania vandana is that it is endemic and native in Lake Rani of Jind (Haryana). It is unsual to find a native species than a invasive species that has been introduced from the environment. The term endemic explains that the organism is not an exotic or a invader. The existence of a diatom specific to Lake Rani describes the change in the environmental conditions the water of Lake Rani had faced with time. This newly identified is not found elsewhere in rivers, canals, puddles or ponds of Haryana. Its closeness with Cymbella affinis and Eunotia bilunaris shows that it is a close relative of these diatoms, but the astonishing feature is that though Cymbella affinis is still found in the Lake Rani but Eunotia bilunaris was not found in Lake Rani in any season neither in any other water bodies of Haryana. Microscopic examination of Eunocymbellarania vandana Plate $1(\mathrm{C})$ shows that it has morphological features resembling Cymbella affinis Plate 1(A) and Eunotia bilunaris Plate 1(B) so it may be a close relative of these two diatoms. Efforts are being made at Diatom culture and research unit Madhuban, Karnal to culture

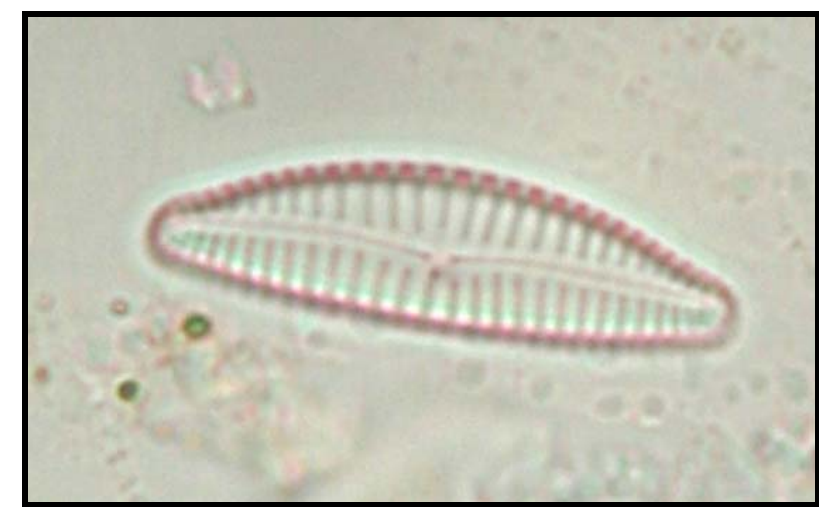

(a)

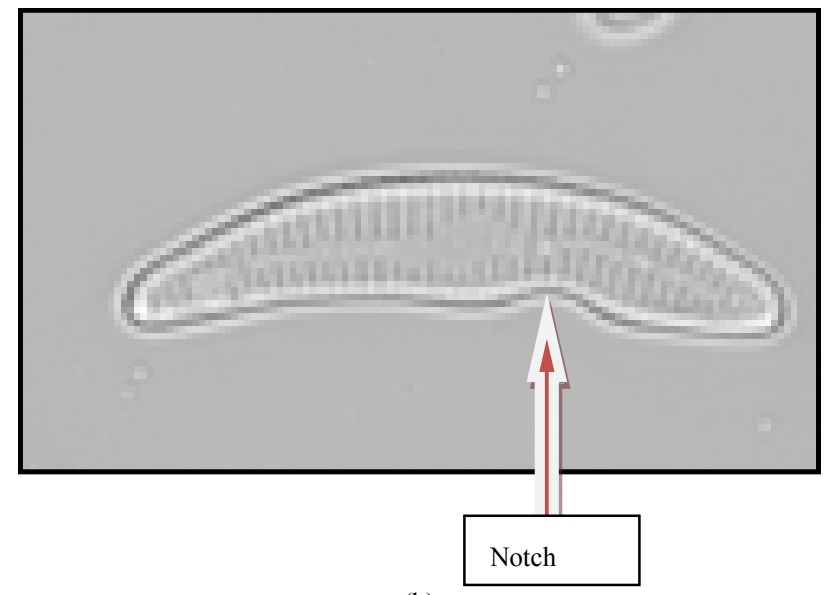

(b)

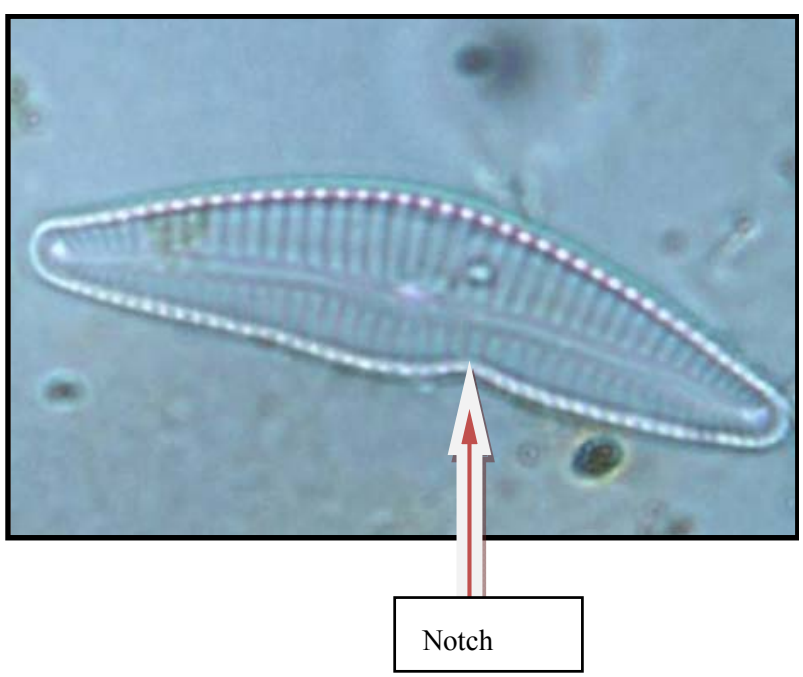

(c)

Figure 2. Cymbella affinis (a) from LRH water site (20082010) and Eunotia bilunaris (b) Picture Courtsey: (Buf. H. du and Baeyer M. M., 2002) a close taxonomic link with Eunocymbellarania vandana (c) from LRH water site (2008 2010) an endemic inhabitant in Lake Rani of Haryana; (a) Cymbella affinis; (b) Eunotia bilunaris; (c) New Genus and species Eunocymbellarania vandana Vinayak Vandana et al. 
this new taxon of diatom, study it at molecular level and compare it with the gene/s in Cymbella affinis and Eunotia bilunaris to discover any diversity if present. The possibility of Eunotia bilunaris turning into extinct can be there because prior to our work on diatom database generation no work had been done. This new genera and species can also be very important from forensic point of view especially in death due to drowning cases. Environmental Indicators should be retrievable under all hydrological conditions, including stagnant and dry and most important should lend themselves to forensic interrogation i.e. palaeoecological assessment. The results ob- tained from there should be incontrovertibly linked to water quality.

Station LRH is a stagnant water body in the centre of the city in which the waste of city is disposed off. Most of the time water colour appeared greenish.

Water quality of LRH site was checked for two consecutive years during the year 2008-2009 and 2009-2010 (Tables 1 and 2) pH, Conductivity and Temperature remained constant for two consecutive year. $\mathrm{pH}$ ranging to $6.5-8.4$ in summers during the month of June, July and August, 6.7 - 8.22 in autumn during the month of September, October and November, 7.18 - 7.72 in winter during the

Table 1. Physical parameters (pH, Temperature, and Conductivity) and Diatom count at station H-5 during the year 20082009. Station LRH: Lake Rani Jind.

\begin{tabular}{|c|c|c|c|c|c|c|c|}
\hline Month \& Year & $\begin{array}{c}\text { Date of } \\
\text { Collection }\end{array}$ & Time & $\begin{array}{l}\text { Vol. } \\
\text { (liter) }\end{array}$ & Temp. & $\mathrm{pH}$ & $\begin{array}{l}\text { Conductivity/ } \\
\text { Salinity } \\
\left(\mathrm{m} \cdot \mathrm{mho}^{-1} \mathrm{~cm}^{-1}\right)\end{array}$ & $\begin{array}{c}\text { Diatom Count } \\
\left(\mathrm{D} / \mathrm{cm}^{2}\right)\end{array}$ \\
\hline June-08 & 11.06 .08 & $7: 22 \mathrm{am}$ & 1.2 & 30 & 6.81 & 0.257 & 406.88 \\
\hline July-08 & 16.07 .08 & $9: 30 \mathrm{am}$ & 2 & 30 & 6.50 & 0.264 & 885.62 \\
\hline August-08 & 11.08 .08 & $3: 00 \mathrm{pm}$ & 1 & 30 & 6.98 & 0.286 & 0 \\
\hline September-08 & 12.09 .08 & $3: 00 \mathrm{pm}$ & 1 & 34.1 & 6.75 & 0.294 & 113.86 \\
\hline October-08 & 15.10 .08 & $2: 00 \mathrm{pm}$ & 1 & 30 & 8.22 & 0.273 & 278.34 \\
\hline November-08 & 14.11 .08 & $3: 25 \mathrm{pm}$ & 1 & 24 & 6.90 & 0.253 & 278.34 \\
\hline December-08 & 18.12 .08 & $2: 26 \mathrm{pm}$ & 1 & 19.7 & 7.18 & 0.230 & 278.34 \\
\hline January-09 & 15.01 .09 & $2: 15 \mathrm{pm}$ & 1 & 19.5 & 7.72 & 0.250 & 366.90 \\
\hline Ferbuary-09 & 16.02 .09 & $3: 30 \mathrm{pm}$ & 1 & 20.4 & 7.22 & 0.240 & 263.15 \\
\hline March-09 & 22.03 .09 & $3: 44 \mathrm{pm}$ & 1 & 29.6 & 7.78 & 0.220 & 151.82 \\
\hline April-09 & 07.04 .09 & $3: 21 \mathrm{pm}$ & 1 & 32 & 7.85 & 0.210 & 111.33 \\
\hline May-09 & 16.05 .09 & $2: 10 \mathrm{pm}$ & 1 & 35 & 7.28 & 0.220 & 328.94 \\
\hline
\end{tabular}

Table 2. Physical parameters (pH, Temperature, and Conductivity) and Diatom count at station H-5 during the year 20092010. Station LRH: Lake Rani Jind.

\begin{tabular}{|c|c|c|c|c|c|c|c|}
\hline Month \& Year & $\begin{array}{c}\text { Date of } \\
\text { Collection }\end{array}$ & Time & $\begin{array}{c}\text { Vol. } \\
\text { (Liter) }\end{array}$ & Temp. & $\mathrm{pH}$ & $\begin{array}{c}\text { Conductivity/ } \\
\text { Salinity } \\
\left(\mathrm{m} \cdot \mathrm{mho} \cdot \mathrm{cm}^{-1}\right)\end{array}$ & $\begin{array}{l}\text { Diatom Count } \\
\left(\mathrm{D} / \mathrm{cm}^{2}\right)\end{array}$ \\
\hline June-09 & 20.06 .09 & $1: 10 \mathrm{pm}$ & 1 & 32.2 & 8.30 & 0.28 & 88.56 \\
\hline July-09 & 20.07 .09 & $2: 05 \mathrm{pm}$ & 1 & 36 & 7.34 & 0.19 & 248.81 \\
\hline August-09 & 21.08 .09 & $2: 47 \mathrm{pm}$ & 1 & 32.7 & 8.40 & 0.22 & 2530.36 \\
\hline October-09 & \multicolumn{7}{|c|}{ Not collected due to non availability of collecting staff } \\
\hline November-09 & 19.11 .09 & $2: 55 \mathrm{pm}$ & 1 & 20.9 & 7.05 & 0.28 & 111.33 \\
\hline December-09 & 17.12 .09 & $2: 45 \mathrm{pm}$ & 1 & 19.1 & 7.22 & 0.18 & 0 \\
\hline January-10 & 13.01 .10 & 10:01 am & 1 & 16.8 & 7.68 & 0.22 & 971.65 \\
\hline Ferbuary-10 & 24.02 .10 & $2: 30 \mathrm{pm}$ & 1 & 18.7 & 7.32 & 0.26 & 414.97 \\
\hline March-10 & 28.03 .10 & $5: 15 \mathrm{pm}$ & 3 & 28.6 & 7.68 & 0.26 & 404.8 \\
\hline April-10 & 26.04 .10 & $7: 40 \mathrm{am}$ & 1 & 30.8 & 7.78 & 0.24 & 303.64 \\
\hline May-10 & 20.05 .10 & $3: 24 \mathrm{pm}$ & 1 & 33.0 & 7.32 & 0.21 & 1376.51 \\
\hline
\end{tabular}


Table 3. Dominating Diatom in different month at LRH site of Haryana, (June 2008-May 2009).

\begin{tabular}{|c|c|c|c|c|}
\hline $\begin{array}{l}\text { Site } \\
\text { Code }\end{array}$ & $\begin{array}{c}\text { Summer } \\
\text { (June-August) }\end{array}$ & $\begin{array}{c}\text { Autumn } \\
\text { (September-November) }\end{array}$ & $\begin{array}{c}\text { Winter } \\
\text { (December-February) }\end{array}$ & $\begin{array}{c}\text { Spring } \\
\text { (March-May) }\end{array}$ \\
\hline $\begin{array}{c}\text { LRH } \\
\text { 2008-2009 }\end{array}$ & $\begin{array}{c}\text { Asterionella, Tabularia, } \\
\text { Fragillaria }\end{array}$ & $\begin{array}{l}\text { Cymbella, Placoneis, } \\
\text { Synedra, Asterionella }\end{array}$ & $\begin{array}{c}\text { Aulacoseira, Fragillaria, } \\
\text { Cyclotella }\end{array}$ & $\begin{array}{l}\text { Gomphonema, Cymbella, } \\
\text { Eunocymbellarania vandana }\end{array}$ \\
\hline $\begin{array}{c}\text { LRH } \\
2009-2010\end{array}$ & Cymbella & Synedra, Cyclotella & $\begin{array}{l}\text { Synedra, Aulacoseira, } \\
\text { Cyclotella }\end{array}$ & $\begin{array}{c}\text { Cyclotella, Aulacoseira, } \\
\text { Synedra, Melosira, Nitzschia, } \\
\text { Sellaphora, } \\
\text { Eunocymbellarania vandana }\end{array}$ \\
\hline
\end{tabular}

Table 4. Dominating and rarely occurring diatom at LRH site of Haryana in Year 2008-2010.

\begin{tabular}{|c|c|c|}
\hline Site & Dominating Diatom & Least Occurring \\
\hline $\begin{array}{c}\text { LRH } \\
2008-2009\end{array}$ & $\begin{array}{c}\text { Asterionella formosa, Tabularia Fragillaria protoneis, Synedra } \\
\text { ulna, Cymbella affenis, Placoneis gastrum, Aulacoseira granu- } \\
\text { lata, Fragillaria capucina, Gomphonema angustatum, Euno- } \\
\text { cymbellarania vandana. }\end{array}$ & $\begin{array}{l}\text { Rhoicosphenia abbreviata, Cyclotella, Melosira varians, Tabu- } \\
\text { laria fasciculata, Licmophora oedipus, Achnanthes minutissima. }\end{array}$ \\
\hline $\begin{array}{c}\text { LRH } \\
2009-2010\end{array}$ & $\begin{array}{c}\text { Synedra, Cyclotella striata, Aulacoseira granulata, Nitzschia } \\
\text { palea, Sellaphora pupul, Eunocymbellarania vandana. }\end{array}$ & $\begin{array}{l}\text { Nitzschia, Surirella linearis, Hantzschia, Brachysira, } \\
\text { Tabularia, Gomphonema trullata, Asterionella Formosa. }\end{array}$ \\
\hline
\end{tabular}

month of December, January and February. In spring during the month of March, April and May pH was 7.28 7.85. Conductivity also didn't show much change and remained between 0.18 to $0.29 \mathrm{~m} \cdot \mathrm{mho} \cdot \mathrm{cm}^{-1}$ during two years. In summer season diatom count was highest $\left(885.62 \mathrm{D} / \mathrm{cm}^{2}\right)$ and lowest $\left(0 \mathrm{D} / \mathrm{cm}^{2}\right)$ in August (2008). In winter season (2008-2009) diatom count varies between $263-366 \mathrm{D} / \mathrm{cm}^{2}$. In the year 2008-2009 $\mathrm{pH}$ increased from June'08 to May'09 (6.86 - 8.22) whereas in the year 2009-2010 pH increased from June'08 to May'09 (7.05 - 8.4). In the year 2009-2010 D/cm² was highest in Aug'09 $2530 \mathrm{D} / \mathrm{cm}^{2}$ with increase in $\mathrm{pH} 8.40$ and conductivity almost constant and temperature a little higher. Diatom diversity was $0 \mathrm{D} / \mathrm{cm}^{2}$ in Sep'09 and Dec'09, in winters varies between 400 - 971 and again increased to $1376 \mathrm{D} / \mathrm{cm}^{2}$ in Spring (May'09).

Common diatom genera which were observed at this site are Aulacoseira granulata, Cyclotella pseudostelligera, Cymbella affenis, Gomphonema angustatum, and Synedra ulna. Seasonal diatoms were Asterionella formosa, Tabularia parva, Fragillaria capucina, and Placoneis gastrum. Rarely occuring diatom genera includes Licmophora oedipus and Eunocymbellarania vandana. Eunocymbellarania vandana was a new genera observed at this site (Tables 3 and 4). Thus Eunocymbellarania vandana is new genus and species to the taxonomic database of diatoms endemic in Lake Rani of Jind, Haryana, India which has not been identified in any existing diatom database.

\section{Acknowledgements}

Author is thankful to Department of Science and Technology, Haryana State Council for Science and Technology, India for sanctioning the funds.

\section{REFERENCES}

[1] F. E. Round, R. M. Crawford and D. G. Mann, "The Diatoms. Biology and Morphology of the Genera," Cambridge University Press, Cambridge, 1990.

[2] N. I. Hendey, "An Introductory Account of the Smaller Algae of British Coastal Waters. Part V: Bacillariophyceae (Diatoms)," Fish Investment Series IV, No. 4, 1964, p. 317.

[3] L. E. Feldt, E. F. Stoermer and C. L. Schelske, "Occurrence of Mophologically Abnormal Synedra Populations in Lake Superior Phytoplankton," 16th Conference Great Lakes Research, International Association Great Lakes Research, Huron, April 1973, pp. 1-1068.

[4] W. H. Thomas, J. T. Hollibaugh and D. L. R. Seibert, "Effects of Heavy Metals on the Morphology of Some Marine Phytoplankton," Phycologia, Vol. 19, No. 3, 1980, pp. 202-209. doi:10.2216/i0031-8884-19-3-202.1

[5] P. C. Adshead-Simonsen, G. E. Murray and D. J. Kushner, "Morphological Changes in the Diatom, Tabellaria flocculosa, Induced by Very Low Concentrations of Cadmium," Bulletin of Environmental Contamination and Toxicology, Vol. 26, No. 1, 1981, pp. 745-748. doi:10.1007/BF01622165

[6] N. S. Fisher, G. J. Jones and D. M. Nelson, "Effects of 
Copper and Zinc on Growth, Morphology, and Metabolism of Asterionella japonica (Cleve) 1," Journal of Experimental Marine Biology and Ecology, Vol. 51, No. 1, 1981, pp. 37-56. doi:10.1016/0022-0981(81)90153-2

[7] J.-R. Yang and H. C. Duthie, "Morphology and Ultrastructure of Teratological Forms of the Diatoms Stephanodiscus niagarae and S. parvus (Bacillariophyceae) from Hamilton Harbour (Lake Ontario, Canada)," Hydrobiologia, Vol. 269-270, No. 1, 1993, pp. 57-66. doi:10.1007/BF00028004

[8] B. H. McFarland, B. H. Hill and W. T. Willingham, "Abnormal Fragilaria spp. (Bacillariophyceae) in Streams Impacted by Mine Drainage," Journal of Freshwater Ecology, Vol. 12, No. 1, 1997, pp. 141-149. doi:10.1080/02705060.1997.9663517

[9] M. D. Dickman, "Benthic Marine Diatom Deformities Associated with Contaminated Sediments in Hong Kong," Environment International, Vol. 24, No. 7, 1998, pp. 749759. doi:10.1016/S0160-4120(98)00060-9

[10] N. Gomez and M. Licursi, "Abnormal Forms in Pinnularia gibba (Bacillariophyceae) in a Polluted Lowland Stream from Argentina," Nova Hedwigia, Vol. 77, No. 3-4, 2003, pp. 389-398. doi:10.1127/0029-5035/2003/0077-0389

[11] A. Cattaneo, Y. Couillard, S. Wunsam and M. Courcelles, "Diatom Taxonomic and Morphological Changes as Indicators of Metal Pollution and Recovery in Lac Dufault (Québec, Canada)," Journal of Paleolimnology, Vol. 32, No. 2, 2004, pp. 163-175. doi:10.1023/B:JOPL.0000029430.78278.a5

[12] E. F. Stoermer, "Atypical Tabularia in Coastal Lake Erie," North American Diatom Symposium, Mobile, 2004.

[13] T. Debenest, J. Silvestre, M. Coste, F. Delmas and E. Pinelli, "Herbicide Effects on Freshwater Benthic Diatoms: Induction of Nucleus Alterations and Silica Cell Wall Abnormalities," Aquatic Toxicology, Vol. 88, No. 1, 2008, pp. 84-94. doi:10.1016/j.aquatox.2008.03.011

[14] M. Schmitt-Jansen and R. Altenburger, "Toxic Effects of Isoproturon on Periphyton Communities-A Microcosm Study," Estuarine, Coastal and Shelf Science, Vol. 62, No. 3, 2005, pp. 539-545. doi:10.1016/j.ecss.2004.09.016

[15] E. L. Duke and B. E. F. Reimann, "The Ultrastructure of the Diatom Cell," In: D. Werner, Ed., The Biology of Diatoms, Blackwell Scientific Publications, Oxford, 1977, pp. 13-45.

[16] L. A. Edgar and J. Pickett-Heaps, "Valve Morphogenesis in the Pennate Diatom Navicula cuspidata," Journal of Phycology, Vol. 20, No. 1, 1984, pp. 47-61. doi:10.1111/j.0022-3646.1984.00047.x

[17] C. Van Den Hoek, D. G. Mann and H. M. Jahns, "Algae-An Introduction to Phycology, Cambridge," Cambridge University Press, Cambridge, 1995, p. 623.

[18] J. W. Rijstenbil, J. W. M. Derksen, L. J. A. Gerringa, T. C. W. Poortvliet, A. Sandee, M. Vandenberg, J. Vandrie and J. A. Wijnholds, "Oxidative Stress-Induced by Copper: Defense and Damage in the Marine Planktonic Diatom Ditylum brightwellii, Grown in Continuous Cultures with High and Low Zinc Levels," Marine Biology, Vol. 119, No. 4, 1994, pp. 583-590. doi:10.1007/BF00354321
[19] J. W. Rijstenbil, "Effects of Periodic, Low UVA Radiation on Cell Characteristics and Oxidative Stress in the Marine Planktonic Diatom Ditylum brightwellii," European Journal of Phycology, Vol. 36, No. 1, 2001, pp. 1-8. doi:10.1080/09670260110001735138

[20] N. A. Andresen and M. L. Tuchman, "Anomalous Diatom Populations in Lakes Michigan and Huron in 1983," Journal of Great Lakes Research, Vol. 17, No. 1, 1991, pp. 144-149. doi:10.1016/S0380-1330(91)71350-6

[21] E. F. Stoermer, "Boomerang-Shaped Synedra in Lake Superior: An Example of a Surviving Mutant Taxon," 4th Meeting of the International Society of Diatom Research, 1998.

[22] J. Pickett-Heaps and D. H. J. A. Tippit Andreozzi, “Cell Division in the Pennate Diatom Pinnularia. V. Observations on Live Cells," Biologie Cellulaire, Vol. 35, No. 3, 1979, pp. 295-304.

[23] J. Pickett-Heaps, "Cell Division in Diatoms," International Review of Cytology, Vol. 128, 1991, pp. 63-108. doi:10.1016/S0074-7696(08)60497-0

[24] M. Lee and C.-W. Li, "The Origin of the Silica Deposition Vesicle of Diatoms," Botanical Bulletin of Academia Sinica, Vol. 33, 1992, pp. 317-325.

[25] T. Debenest, J. Silvestre, M. Coste, F. Delmas and E. Pinelli, "Herbicide Effects on Freshwater Benthic Diatoms: Induction of Nucleus Alterations and Silica Cell Wall Abnormalities," Aquatic Toxicology, Vol. 88, No. 1, 2008, pp. 84-94. doi:10.1016/j.aquatox.2008.03.011

[26] C. A. Agardh, "Conspectus Criticus Diatomacearum," Cymbella Cymbiformis, Vol. 1-4, 1830, pp. 1-16.

[27] K. Krammer, "Diatoms of Europe-Cymbella," A. R. G Grantner Verlag Ruggel, Vol. 3, 2002, pp. 1-193. doi: $10.2307 / 3062152$

[28] E. Alles, M. Norpel-Schempp and H. Langebertalot, "Zur Systematik Und Okologie Charakteristischer EunotiaArten (Bacillariophyceae) in Elektrolytarmen Bachoberlaufen," Nova Hedwigia, Vol. 53, 1991, pp. 171-213.

[29] J. Kwandrans, "Diversity and Ecology of Benthic Diatom Communities in Relation to Acidity, Acidification and Recovery of Lakes and Rivers," Diatom Monographs, Vol. 9, 2007, pp. 1-169.

[30] V. Sladecek, "Diatoms as Indicators of Organic Pollution," Acta Hydrochimica et Hydrobiologica, Vol. 14, No. 5, 1986, pp. 555-566. doi:10.1002/aheh.19860140519

[31] R. Patrick, "Factors Effecting the Distribution of Diatoms," The Botanical Review, Vol. 14, No. 8, 1948, pp. 473-524. doi:10.1007/BF02861575

[32] J. P. Descy and M. Coste, "A Test of Methods for Assessing Water Quality Based on Diatoms," Negotiations of the International Association Limnology, Vol. 24, 1991, pp. 2112-2116.

[33] N. G. Cameron, "The Representation of Diatom Communities by Fossil Assemblages in a Small Acid Lake," Journal of Paleolimnology, Vol. 14, No. 2, 1995, pp. 185223. doi:10.1007/BF00735481

[34] J. R. Carter and R. J. Flower, "A New Species of Eunotia, E. Pirla Sp. Nov., from Woolmer Pond, an Acid Pool in 
the Southeast of England," Diatom Research, Vol. 3, No. 1, 1988, pp. 1-8. doi:10.1080/0269249X.1988.9705013

[35] J. F. Pierre, "Algal Community and Acidity of the RuisBuckets of the Vosges Massif," Bull. Acad. Soc. Lor. Sci., Vol. 35, 1996, pp. 139-156.

[36] R. Patrick and C. W. Reimer, "The Diatoms of the United States. I. Monographs of the Academy of Natural Sciences of Philadelphia," Livingston Publishing Company, Pennsylvania, 1966, p. 688.

[37] H. Kobayasi, K. Ando and T. Nagumo, "On Some Endemic Species of the Genus Eunotia in Japan," Proceedings of the 6th International Diatom Symposium, Koenisgtein, 1981, pp. 93-114.

[38] H. Lange-Bertalot and D. Metzeltin, "Indicators of Oligotrophy. 800 Taxa Representative of Three Ecologically Distinct Lake Types," Koeltz Scientific, Königstein, 1996.

[39] A. J. Peabody, "Diatoms and Drowning-A Review," Medical Science Law, Vol. 20, No. 4, 1980, pp. 254-261.

[40] A. J. Peabody, "Forensic Science and Diatoms," In: E. F. Stoermer and J. P. Smol, Eds., The Diatoms: Applications for the Environmental and Earth Sciences, Cambridge University Press, Cambridge, 1999, pp. 413-418.

[41] P. A. Siver, W. D. Lord and D. J. A. Mccarthy, "Forensic Limnology: The Use of Freshwater Algal Community Ecology to Link Suspects to an Aquatic Crime Scene in Southern New England," Journal of Forensic Science, Vol. 39, 1994, pp. 847-853.

[42] M. S. Pollanen, L. Cheung and D. A. Chaisson, "The Diagnostic Value of the Diatom Tests for Drowning. I. Utility: A Retrospective Analysis of 771 Cases of Drowning in Ontario, Canada," Journal of Forensic Science, Vol. 42, 1997, pp. 281-285.

[43] S. Krstic, A. Duma, B. Janevska, Z. Levkov, K. Nikolova and M. Noveska, "Diatoms in Forensic Expertise of Drowning-A Macedonian Experience," Forensic Science International, Vol. 127, No. 3, 2002, pp. 198-203. doi:10.1016/S0379-0738(02)00125-1

[44] N. G. Cameron, "The Use of Diatom Analysis in Forensic Geoscience,” In: K. Pye and D. J. Croft, Eds., Forensic Geoscience: Principles, Techniques and Applications, Geological Society, London, Vol. 232, 2004, pp. 277280. doi:10.1144/GSL.SP.2004.232.01.25

[45] H. Du Buf, "Automatic Diatom Identification," World Scientific Publishing, Singapore, 2002. doi:10.1142/9789812777867 0001

[46] M. S. Pollanen, "Diatoms and Homicide," Forensic Science International, Vol. 91, No. 1, 1998, pp. 29-34. doi:10.1016/S0379-0738(97)00162-X
[47] F. Husdtedt, "Die Susswasser-Flora Mitteleuropas. Heft 10: Bacillariophyta (Diatomaceae)," Reprint 1976, Otto Koeltz Science Publishers, Konigstein, 1930, p. 466.

[48] F. Husdtedt, "Systematische Und Okologische Untersuchungen Uber Die Diatomeenflora Von Java. Bali Und Sumatra," Archiv für Hydrobiologie, Supplement, Vol. 15, 1938-1939, pp. 131-177, 187-295, 393-506, 638-790, Vol. 16, pp. 1-155, 274-394.

[49] F. Husdtedt, "Die Diatomeenflora Des Fluss-Systems Der Weser Im Gebiet Der Hansestadt Bremen,” Reprint 1957, Otto Koeltz Science Publishers, Konigstein, 1957, p. 260.

[50] F. Husdtedt, "Die Kieselalgen Deutschlands, Osterreichs Und Der Schweiz Unter Berucksichtigung Der Ubrigen Lander Europas sowie der angrenzenden Meeresgebiete. 2 Teil," Reprint 1977, O. Koeltz Science Publishers Konigstein, 1959, p. 845.

[51] R. Patrick, C. W. Reimer and G. S. Yong, "The Diatoms of the United States. Monographs of the Academy of Natural Sciences of Philadelphia," Livingston Publishing Company, Pennsylvania, 1975, p. 213.

[52] K. Krammer and H. Lange-Bertalot, "Bacillariophyceae. 1. Teil. Naviculaceae," In: J. Ett, J. Gerloff, H. Heymig and D. Mollen-Haver, Eds., Subwasserflora von Mitteleuropa 2/1, Gustav Fischer Verlag, Stuttgart, New York, 1986, pp. 1-876.

[53] K. Krammer and H. Lange-Bertalot, "Bacillariophyceae. 2. Teil. Bacillariaceae, Epithemiaceae, Surirellaceae," In: J. Ett, J. Gerloff, H. Heymig and D. Mollen-Haver, Eds., Subwasserflora von Mitteleuropa 2/2, Gustav Fischer Verlag, Stuttgart, 1988, pp. 1-596.

[54] K. Krammer and H. Lange-Bertalot, "Bacillariophyceae. 3. Teil. Centrales, Fragilariaceae, Eunotiaceae,” In: J. Ett, J. Gerloff, H. Heymig and D. Mollen-Haver, Eds., Subwasserflora von Mitteleuropa 2/3, VEB Gustav Fischer Verlag, Jena, 1991, pp. 1-576.

[55] K. Krammer and H. Lange-Bertalot, "Bacillariophyceae. 4. Teil. Achnanthaceae," In: J. Ett, J. Gerloff, H. Heymig and D. Mollen-Haver, Eds., Subwasserflora von Mitteleuropa 2/4, Fisher, Stuttgart, 1991, pp. 1-437.

[56] R. Simonsen, "Atlas and Catalogue of the Diatom Types of Friedrich Hustedt," J. Cramer, Berlin, 1987.

[57] H. P. Gandhi, "Freshwater Diatoms from Sagar in Mysore State," Journal of the Indian Botanical Society, Vol. 38, 1959, pp. 305-331.

[58] J. B. M. Alice, "Phytoplankton Sampling with Sedgwick Rafter Cell," Limnology and Oceanography, Vol. 16, No. 1, 1971, pp. 19-28. 